\title{
THE SUBJECTIVE DIMENSION OF SECURITY EDUCATION
}

\author{
Col. Krzysztof DRABIK, Prof. PhD \\ k.drabik@akademia.mil.pl \\ Faculty of National Security \\ War Studies University, Warsaw, Poland
}

\begin{abstract}
Subjectivity in education is not a new issue. It defines the position and role of participants in educational processes (teacher, students). However, education combined with problems of security may raise some doubts in interpretation. It is about identifying the subjects of security. If you adopt the premise that a set of security subjects is not restricted to man and social groups, then security education should also consider other subjects. Moreover, the hazard society, as a product of the postmodern era involves the need for scientific research and public discussion about man as the subject in the process of education and social relations in general.
\end{abstract}

Keywords: education, security, subjectivity

\section{Security Education}

The structure of the event -security education-indicates two key processes defining the character of human life. On the one hand, it is about gaining knowledge and exploring the world, on the other, it is about taking such actions which assist those cognitive efforts and ensure permanence of existence. Security education combines these two areas of human activity - epistemological and ontological. The sequence of these processes expressed in the defined phrase indicates the 
main role of education in forming security. It seems, however, that taking into consideration etymology and a set of designates proper for the notion of security, the permanence of existence (in its biological meaning) conditions higher forms of activity and the creation of all cultural artefacts. It is, therefore, worthwhile looking at the reverse sequence of the mentioned processes where forming security is primary with respect to conscious educational efforts. We thus speak about forming security for education. It must be emphasised that the above aspect of the dissertation concerns security understood in terms of a basic need, namely in the meaning attributed to it by an American psychologist, Abraham Maslow, and by the existentialists. Existence in the physical sense constitutes a pillar of more complex cultural structures including conscious and telelological educational processes. The construction of a dignified form of existence requires physical and somatic stability which is indispensable for steps on the higher levels of abstract thinking. The proper basis for Maslow`s structure of needs is the category of security embracing all physiological needs integrated with the needs of higher order. This universality of security implies the necessity to search for a definite framework which could be later reduced to the methodologically operational fields of research. We may formulate a thesis that all human existence is a set of compiled external and internal factors each of which constitutes an element developing security. Therefore, security is an integral attribute of human existence regardless of its more concrete aspects. Irrespective of what theoretical prism we adopt, man as an individual or member of a social group (ontological, epistemological, ethical), security will be the key problem in the further analysis of its existential condition. Following the ontological train of thought which shaped existentialism and assumed that existence precedes essence, security which supports this existence becomes the constitutive category. However, reducing security to the level of physical existence does not exhaust the in-depth richness of designates included in this concept. Before I proceed to underline the significance of security reaching beyond biological continuity, it is worthwhile looking at security in anthropological terms important from the educational perspective. The area of meaning of the discussed concept is outlined by the anthropological and humanist dimension invoking man as a subject. Close integration of man and security as his attribute is the starting point for further theoretical considerations. Security understood as a general term has no meaning which can be assigned to it with reference to a subject. It is a strictly abstract term for which the right 
defining framework proper for the logic of defining (proximum and differenctiam specificam) cannot be found. Abstractness of security in the dimension beyond the subjective corresponds to the stoic ontology of space and time. Neither category is classified as part of the set of material artefacts so they are non-existent (cf. Tatarkiewcz 2003, p. 130). Therefore, security analysed beyond a subject is non-existent. The subjectivity of security is focused on man and his social group.

Anthropological and humanist provenance of security is not limited to biologically determined needs whose satisfaction conditions survival. Remaining on the level of sheer biological survival would mean extending the range of meaning of the discussed term to all living nature. However, understanding of security in the abstract context characteristic for products of both material and non-material culture restricts the set of designates of all animal species. Security cannot be reduced solely to biological determinants conditioning physical survival. ${ }^{1}$ Two factors make up the cultural aspect of security: ethical and teleological. The first defines the aspect of human dignity, man being a creature of reason and dignity. Human life is an infinite value sanctioned not only by relative morality and absolute ethics, but also by the standards of juridical law (rights of man). The second indicates the goals which open development perspective. Those factors are emphasised in the philosophical understanding of security which is closely connected to the values of dignity and development.

A higher cultural level of reflection on security opposed to primary naturalism finds its reflection in security education. Security is the necessary condition to undertake educational effort, but the educational process itself elevates man to a higher level of moral development. Man becomes an expressis verbis cultural subject whose security reaches far beyond biological determinants.

1 Abstract context determines anthropomorphic understanding of security. It is man who shapes security not identified only and exclusively with physical survival. He is able to transcend the biological dimension of life, which is important but does not exhaust the richness of meaning ascribed nowadays to security. Man creates culture of which one dimension is security, so he creates the culture of security which distinguishes him as a representative of a species in the set of other species of the living nature (Gazzaniga 2011, p.45). 


\section{Three criteria of subjectivity}

The issue of security perceived as an integral attribute of human life in the total meaning - biological and cultural- reflects a two-fold human nature: on the one hand, remaining in the fetters of biologism embracing all species, and on the other, transcending this naturalism and opening a cultural perspective specific for man. The above vision of man is not a new thing, on the contrary, it grows out of a rich philosophical tradition of thinking about the duality of human nature, but it influences the modern context of research on security ${ }^{2}$. Based on this, we may accept at least three research perspectives: naturalist, cultural, naturalist-cultural. The first one embraces the problem of security reduced to the process of survival as such without any "quality" features. What is important is physical survival sustaining the chain of phylogenetic evolution, biological survival, transmission of genes and adaptation to the conditions of the natural environment. This perspective embraces all ecosystems and does not ascribe any special status to man. He is one of many elements of the ecological system. The naturalist perspective raises security to the level of universality. So, each element of living and non-living nature may be characterised from the angle of security. The main criterion of estimated security will be the quantitative aspect reduced to preserving the continuity of existence and fulfilling the proper role in the given ecosystem. The cultural perspective defines the limits of a set of subjects and raises the problem of defining security to a higher level of interpretation. What becomes important is the context of quality, axiology, culture and abstractness. The physical existence, considered a condition sine qua non in general, is not that much important as quality aspects which investing life with a sublime spiritual and idealistic meaning reaching far beyond the instinct of self-preservation determined by the somatic aspect. The cultural perspective invests security with sensu stricto humanist meaning. The set of subjects is restricted to the homo sapiens species which is able to shape its existence according to the criteria of rationality not determined by the biological aspect. Emphasising the quality aspect indicates that the subject of security is

2 Immanuel Kant formed an accurate statement reflecting the dual nature of man: "There are two things filling the mind with an always new and growing feeling the more often we think about them. The sky full of stars above me and the law inside me." The sky full of stars exemplifies nature; moral law is the image of human rationality (Kant 1972, p.256). 
man (social group) and research into the conditions of the external environment creating objective security space comes down to the assessment of the influence of this environment on the quality of the subject's existence. Security in the cultural perspective has an anthropological dimension and epistemological meaning as long as it refers to man. In literature on the subject, the cultural perspective creates a theoretical basis for personal safety (cf. Cieslarczyk 2011; Urbanek 2015; Drabik 2013). The essence of developing safety is to give an ethical status to the subject which is not realised by survival as such but a dignified life respectively to the moral axiology accepted and internalised in the social environment. It is the key aspect for developing the sense of security, where the ethical aspect (connected to dignity) acquires special meaning. Another indicator of the cultural identification of security is development, which not only testifies in itself to the process related character of security but defines its teleology. We may think that the aim of the process of developing security is not only biological survival but rather in sometimes refined forms of civilisational and cutural identity ${ }^{3}$. The ideas of ethics and purposefulness inscribed into the definition of security define its anthropological and humanist etiology.

The third perspective which combines the two previous ones seems to reflect best the meaning of security linking physical and biological aspects with ethical and cultural. I think, however, that in contemporary reflection on security what prevails is the cultural perspective which transposes the weight of survival on the abstract level respectively to the modern level of civilisational development.

3 A modern man is involved in the structure of cultural artefacts conditioning criteria of security in both positive and negative meaning. The products of science and technology may generate previously unknown threats developing the character of modern pursuit of existential stability. The subjective sense of security does not issue now from naturalistic reasons but those of culture and civilisation. Relative satisfaction of physiological needs initiated transition to a higher level of thinking about security determined by the category of risk. This problem has been highlighted by Ulrich Beck who stated that "risk society has new sources of conflict and consensus. Instead of overcoming privation we are overcoming risk" (Beck 2002, p.62). 


\section{Cultural aspect of security education}

The image of this cultural trend is security education evolved from the level of preparation for defence and defence education and embracing a broader spectrum of problems extending beyond the information about mandatory defence procedures and useful skills. Security education became a source of the multifaceted development of man integral in developing security. Education causes this development to be orderly, not chaotic, and directed towards gaining knowledge, social competence and most of all creating a bridge to the world of values and their internalisation. Security education puts forward goals which initiate the process of development in the circle of socially recognised axiology. It reflects correlated ethical and teleological factors. The aim is to construct a dignified form of existence and the objective of education serves to achieve the desired shape of this existence. Therefore, aims and values also defining the process related character of developing security by conscious educational actions define its ontological dimension where man is both the subject and goal of securitology efforts. Education supports developing the culture of security and prepares man to face modern threats specifically defined by the dynamics of civilisation transformations. The subject of the education process is man as the reason and goal of the channelled transfer of knowledge.

The cultural perspective which gives direction to modern reflection on security and confirms its humanist dimension is not only a theoretical statement that can be more or less useful in more academic discussions. The contemporary level of civilisation development, almost universal systems, complexity, multifaceted global aspect, high level of specialisation; all these justify the advantage of this cultural concept. Now, the matter is not to survive in the conditions of the laws of nature but to survive in the conditions under the major influence of technology entities modifying the natural environment. In order to prepare appropriately for the actions eliminating the negative influence of reality modified by civilisation, the more advanced programmes of education appear to be necessary, which allow these threats to be identified at all levels of education and inform about the methods to deal with them.

The current position and status of education in the processes developing security cannot be overestimated. The role of educational activities is even more 
important now when the phenomena of civilisation and cultural modification of man`s surroundings are progressing intensively. The high level of contemporary modernisation action raised man to another level of thinking about the past and future. One of these paradigms rooted in the modern discourse about security is the principle of subjectivity (personal security) assuming the supremacy of the cultural perspective over the naturalist one where man is the centre of efforts to develop security, including its educational aspects. All activity directed towards development of security is embedded in the above paradigm, no matter what kind it is and how it is classified.

\section{Education in the risk society}

In the cultural perspective, other theories are crystallising which aspire to the status of the theoretical paradigm reflecting modern quality differences in security. The concept of risk must be emphasised. The reasons for the rise of the importance of risk must be sought in gradual deconstruction of traditional lifestyles rooted in the past. Cultural values rooted in the tradition dominating in the past have no significant influence on projecting the future and counteract thinking connected with it. The break with the past gave rise to a feeling of uncertainty, existential disorientation and enhanced the risk of taking "nonstandard" decisions not established in history. The risk is closely connected with responsibility and internalises anxiety about the effects of the undertaken action. The purpose of education for safety is to minimise risk in times when traditional bonds between past and present are breached. There is an interesting connection between the narrowing down of the space of informal transmission of values between generations and broadening of the space of institutional educational influence aimed at inducing man (young, adult and elderly) into functioning in the complex world of permanent risk. Risk arises from the undefined nature of what is to come, even less predictable now that past values have degenerated due to dynamic changes within one generation. Anthony Giddens emphasises the fact that the concept of risk is particularly significant in a society which breaks with its past and traditional ways of acting and, thus faces, an open but uncertain future" (Giddens 2007, p. 153). The risk is generated by contesting cultural systems rooted 
in the past, and while modified by the dynamics of civilisation changes, leads towards counterfactual indeterminacy ${ }^{4}$.

As I have already mentioned, the purpose of security education is, among other things, to minimise the above risk through emphasising the role of man as a subject consciously creating reality and gaining the knowledge and values necessary to take decisions that strengthen personal security. So, the traditional values of education have been recently strengthened by the issue of developing security as a specific determinant of our times. The increase of risk not only follows from the fact of broken bonds between generations, but also from the universal cult of individuality and liberalism connected, on the one hand, to the benefits of personal freedom, and on the other, to the threats issuing from the lack of traditional axiological references. The idea of individual creation seems to be attractive, but in practice instills the feeling of threat resulting from the burden of responsibility for individuals' own decisions and acts.

Criticism of historicism together with the universal cult of liberalism creates dualism of freedom and security characteristics for the post-modern era where man, metaphorically speaking, stands at the crossroads between the route leading to the safe traditional axiology of social relations solidified by generations, and the route to the space of indefinite possibilities, a non-standard form of creation and, thus, to a greater responsibility for the effects of undertaken actions. Failure may lead to loss of the accepted axiological system based on faith in individual possibilities of changing the surrounding world. The hazard connected with modern social cultural atomism consists in unstable internal structures. If passing down values from generation to generation is in deficit, individual basis of evaluation must be constructed, consistent with universal general norms but differentiated enough to emphasise the diversity and specificity of a concrete person. Individualism supports the significance of differentiating elements and its creation is connected with freedom and creativity. However, freedom awakes apprehensiveness and uncertainty as to the shape of the future. The question

4 Karl Popper discussed the subject of the breach with the past as the basis for construction of the present and future calling this problem criticim of historicism. According to the philosopher discovery of the laws of history and applying them for prediction of the events does not fulfill the criteria of scientific method. There is a fundamental difference between scientific prediction and historical prophecy (Popper 2006, p.6). 
arises whether each individual is able to make an effort to construct a system of axiological principles which would not only be stable but make an effective anchorage for justifying their actions? The attempt to answer the above doubt should be preceded by quoting some reflections on modern man's search for security. Giddens, quoted earlier, distinguishes between two kinds of awareness: practical and reflective. Practical awareness defines the set of everyday routines which do not grow from any profound reflection or decision play but are a repetitive cultural ritual. This everyday routine, well known activities, are for man a guarantee of security, of continuation of a sequence of events. Routine makes the future foreseeable and, therefore, known and secure. Values crystallised in cultural transmission and defined by tradition as well as routine forms of everyday life form the most recognisable areas of security. Risk appears in spaces not well enough defined by tradition and routine. Giddens emphasises the role of tradition in creating a bridge between past and present through which the latter is more foreseeable, apt to make prognosis and planning and so bearing a smaller "charge" of risk; "time is not an empty dimension, and a consistent way of life refers the future to the past. Also, tradition creates feelings of permanence that have a cognitive aspect mixed with moral feelings. It is so because it should be so" (Giddens 2007, pp. 68-69).

\section{Subjectivity in freedom vs effects of modernisation}

Erich Fromm, while analysing the issue of the freedom of man and his subjectivity, points to the vital problem of facing responsibility whose significance was formed during the process of release from the bonds of nature (freedom from) and creative change of the world (freedom to). Natural bonds, while limiting man, were an existential map where it was easy to identify a consistent strategy for a life of low risk. Positive freedom took away from man the possibility to use "natural instruction". As Fromm emphasises, "the development of man's intelligence and emotions on many levels and his unprecedented participation in achievements of culture were accompanied by a disparity between "freedom from" and "freedom to". This lack of proportion between freedom from all bonds and the lack of possibility for positive realisation of freedom and personality led to an escape in panic in Europe into new bonds or at least to total indifference" (Fromm 2005, p. 51). 
It is worthwhile underlining that development of civilisation and its accompanying changes in all areas of human life are not characteristic for modernity, but its course and dynamism may cause anxiety. The course of progress accelerated so much that traditional bonds between generations were broken, those which guaranteed the transmission of constitutive principles sustaining their importance in generation after generation. This transmission has now been disrupted by the dynamics of change followed by the inadequacy of material artefacts and moral values. The disruption to the function of traditional communication channels joining one generation to the next is not the only criterion for describing the existential situation of a modern man. The "side effects" of the modernisation process are also important because they have a negative impact not only on the internal axiological structure but also on the biological survival of subjects. Modern dynamism of the postindustrial world influences deconstruction of traditional faith in progress, including scientific (technological) progress. Modernist products of contemporary civilisation went beyond the positive practical context established in history assuming gradual liberation from the bonds of nature and simplification of the forms of everyday activities. The modernisation aim itself became deformed and started to be perceived as a threat which must be dealt with. A. Giddens states that the world we live in is dangerous and full of tension. It contributes not only to a weakening of faith in a happy and more secure social system but also induces reservations about it" (Giddens 2008, p. 7). It is hard to imagine a more tragic existence of a subject when the clear-cut nature of positive perception of development goals is undermined and even requires deep verification. What is interesting is that the civilisational progress is not a goal in itself but creates control mechanisms. The means and methods are searched for to reduce the negative effects of modernity processes. It demonstrates two directions and the specific dualism of civilisation threats on the one hand, and the methods of its reduction. Modern relevance and the importance of security issues are the result of a need to verify the influence of civilisation artefacts on their producer. Nature in itself is not a threat, but it is a threat as a result of its uncontrolled modification. A thesis may be ventured that man is a threat to himself and, at the same time, is the subject of developing security processes. The problem of consequensialist dualism embedded in modernisation processes was presented by Urlich Beck "making nature useful and liberating man from all traditional constraints are not the only concerns now, but also the problems 
which are a consequence of technological and economic development itself.(...) Promise of security intensifies with the growth of risk and must be constantly reaffirmed through cosmetic or actual interference in technological and economic development in the face of vigilant and critical public opinion" (Beck 2002, p. 28). Risk is part of human nature, as man constantly pursues existential balance which is not permanent in itself. Andrzej Kiepas emphasises, while analysing A, Gehlen's concept of "deficiency", that man pursues the condition of balance which is not something biologically conditioned because of a lack of specific features. Man is compelled to compensate for the lack of biological equipment with the products of technology, so he is trying to maintain the balance between nature and culture. "Man is doomed to search for other than natural methods to achieve balance in the world and therefore is an active and working creature (...) The achieved balance has no permanent character but can be reproduced by repetition of certain actions which lead to creation of a relatively permanent world of social and cultural institutions" (Kipeas 2007, pp. 13-14).

In light of the above, the following threats must be named which are, at the same time, a challenge in forming concepts and strategies for developing security, including challenges facing security education:

- disruption of communication between generations

- category of risk ( risk of responsibility)

- use of technology products (among others, implementation of military technology, modern biomedicine)

\section{Teleology of security education}

In the context of new postmodern principles criticising some metatheories, the subjectivity of man is not questioned but, on the contrary, emphasised, but on the other hand, endowing it with some concrete and practical content is to raise doubts. This is the background for the main role, as mentioned above, of security education understood as man's development oriented process supporting him in the search for identity in the conditions of complex systems and sets of relative values. In my opinion, the overriding goal of security education as perceived from a general perspective, is development of a bridge between tradition and modernity, 
the culture of metatheory and culture of risk, between the lifestyles rooted in history and the contemporary cult of individual creation and positive freedom. It is not only about reducing the gap between tradition and modernity, but about development of new models of activity, norms and principles accelerating the axiological anchorage processes. Education should be neither reproductive nor utopian (counterfactual) but searching for "the golden mean" in developing a model of a modern man-subject. If modernisation is problematic, it is directly linked to defining a modern concept of subjectivity. Man himself is both creator and beneficiary of modernisation. The subject must be constantly defined in the environment of dynamic conditions and new justifications must be introduced. What predestines man to the role of subject today is the changeability and axiological relativity and dynamics of change in the world of social entities. These processes enhance the frequency of defining and justifying the place and role of man in modern social systems. Therefore, personal security problems appear to be an important and topical issue causing, as a consequence, development of theoretical premises and the practice of security education.

Tendency to build personal security on the basis of routine and fairly predictable actions is not extraordinary but follows from natural human needs to be rooted in something known and safe. Criticism of attitudes demonstrating symptoms of escape from risk and uncertainty should take into consideration the inclination and need to search for existential stability established by known and repeated acts identified with security. On the other hand, excessive passivity and escape from positive freedom are not favourable for development, which is an integral element definiens of security in the humanist meaning. Security education faces a challenge to search for a concept of man adequate for modern cultural conditions and combing values rooted in tradition and new perspectives of personal creation where the risk level does not overstep an acceptable threshold. The point is not to propagate the need to take permanent risks but to gain knowledge and skills facilitating appropriate decisions in the risk society. Knowledge, information, experience integrated and an internalised set of moral values create favourable conditions for minimising risk and making phenomena and processes more predictable in spite of more imponderables than ever before. The objective of education is to support substantially and organisationally the transmission of knowledge, experience, values and to develop orientation in the maze of modern systemic relations. Philosophy is helpful in educational efforts as a general reflection about 
the world and man identifying, analysing and synthesising contemporary trends and phenomena featuring dynamic modernisation. Ryszard Rosa emphasised the idea of integration of philosophy and education in developing worthy forms of existence while stating that "in modern complex and dynamic conditions of the early $21^{\text {st }}$ century, many philosophers and scientists are in favour of broader consideration of philosophical concepts in paedagogical research and educational practice to define objects, goals and content of education" (Rosa 2010, pp. 10-11). Filling the gap between generations and searching for axiological identity requires development of a consistent theory of man able to face modern threats, which is certainly supported by the strategy of interdisciplinary cognitive reflection. Philosophical ideas are a theoretical space, a horizon of values, principles, a way of understanding reality which is supportive of developing consistent educational practice considering the complexity of natural environmental, social and cultural reality. Educational actions are a reflection of the operationalisation of available theoretical approaches transposed on concrete approaches, behaviour, life strategy and culture of security. Philosophical conceptualisation of cognitive space combined with educational practice based on the principle of subjectivity defines a proper foundation for developing personal security. This combination of achievement of academic disciplines allows humanism to be applied, proper for tradition, to contemporary conditions of the society of risk and permanent uncertainty resulting from the lack of axiological roots. Mieczysław Łobocki (1998, p. 101) emphasised the constitutive role of the humanist line in defining subjectivity while analysing the moral postulate of altruism in education. Humanism makes a subject of man, situating him in the space of freedom and making him responsible for shaping his own fate and, what is important, investing him with the status of a man of dignity. The sense of worthiness and personal dignity is the key element to modern understanding of security. To be secure means to be aware of your dignity, which elevates the problem of developing security to the abstract level of ethics and higher culture, as I suggested above ${ }^{5}$. Janusz Swiniarski emphasises the importance of the humanist line in a philosophical reflection on security: "It is a line of man's affirmation. It is called philosophical antropocentrism. (...) Therefore, such subjectivist aspects of security as ethical, political, aesthetic and

5 Philosophical understanding of security emphasises the evaluation aspect in the existence of man who is first of all a creature of dignity. The dignity dimension is constitutive for defining security and its cultral provenience. 
economic have deep philosophical roots. They link security to the desire for feeling and pursuit of good, perfection, beauty and justice" (Świniarski 1998, p. 11). This philosophical plane of security defines general frames of educational actions to develop practice (resources and methods) of education, notwithstanding the degree of dynamics and the complexity of modernisation processes of today. Educational practice should be established in general and universal axiology made practical in the changeable space of postmodernist dynamics. Educational effort in transmission of values as part of education are aimed at developing a form of existence in dignity and culture and functioning in the social environment. Those efforts would not be possible without considering the principle of subjectivity constituting the education process. It must be accepted that modern education in general, and security education in particular, should affirm man and his dignified form of existence. Modernisation processes of today and the threats which they involve define the necessity to work on modern specific ways (methods) to counteract disturbing and depreciating factors (threats). But this methodological reductionism adequate for the contemporary complexity of phenomena should also consider a set of cardinal values affirming te value and dignity of man. The relation between modern technologised reality and increased importance of educational values respectively were emphasised by Andrzej Pieczywok "significance of security education increases with development of Western (Latin) civilisation, industrialisation, urbanisation, technologising and computerisation. It was, as it were, imposed : by correction in thinking about man and his vocation and methods of action, ecological arguments and about limits of economic growth, self-destructive technological progress and the indispensable character of sustained development" (Pieczywok 2011, p. 71). Education is not only supposed to emphasise the subjective dimension of developing security but invest it with the proper content of educational activity which can most comprehensively demonstrate the specific character of modern times determined by axiological multiplicity, relativism, deficit of transfer of experience of past generations and their inadequacy for modern forms of social life. It seems that the developing trend in critical education is adequate for the dynamics of changing the postmodern world where the criterion of subjectivity retains its importance. Critical education promotes creative approaches, faces challenges brought by the reality of globalisation and technology. A. Pieczywok underlines that "adoption of this 
doctrine is supposed to make education a factor of improvement in people's lives and helps to define the directions of desirable changes and ways to implement them" (Pieczywok 2012, p. 335).

\section{References}

Beck, U., 2002. Społeczeństwo ryzyka. W drodze do nowoczesności. Trans. S. Cieśla. "Scholar" Warsaw.

Cieślarczyk, M., 2011. Teoretyczne i metodologiczne podstawy badania problemów bezpieczeństwa personalnego. UPH, Siedlce.

Drabik, K., 2013. Bezpieczeństwo personalne i strukturalne. AON, Warsaw.

Fromm, E., 2005. Ucieczka od wolności. Trans. O. and A. Ziemilscy. Czytelnik, Warsaw. Gazzaniga, M., 2011. Istota człowieczeństwa, Co sprawia, że jesteśmy wyjatkowi. Trans. A. Nowak. Wyd. „Smak Słowa”, Sopot.

Giddens, A., 2007. Nowoczesność i tożsamość. Trans. A Szułżycka. PWN, Warsaw.

Giddens, A., 2008. Konsekwencje nowoczesności. Trans. E. Klekot. Wydawnictwo Uniwersytetu Jagiellońskiego, Kraków.

Jarmoch, E., Jaroń, J. and Trzpil, I.A., (eds) 2007. Ewolucja koncepcji natury ludzkiej wświetle naukfilozoficznych, psychologii, teologii i politologii. Wydawnictwo Akademii Podlaskiej, Siedlce.

Kant, I., 1972. Krytyka praktycznego rozumu. Trans. J. Gałecki. PWN, Warsaw.

Kiepas, A., 2007. Technika a natura ludzka - dwa paradygmaty: Jean Jacques Rousseau i Immanuel Kant. In E. Jarmoch, J. Jaron, and I.A. Trzpil (eds), Ewolucja koncepcji natury ludzkiej $w$ świetle nauk filozoficznych, psychologii, teologii $i$ politologii. Wydawnictwo Akademii Podlaskiej, Siedlce.

Łobocki, M., 1998. Altruizm i wychowanie. Wydawnictwo Uniwersytetu Marii CurieSkłodowskiej, Lublin.

Popper, K.R., 2006. Spoleczeństwo otwarte i jego wrogowie. Vol.1. Trans. H. Krahelska. PWN, Warsaw.

Rosa, R., Świniarski,J.,(eds) 2010.Edukacja dla bezpieczeństwa-bezpieczeństwo wedukacji. Uniwersytet Przyrodniczo-Humanistyczny, Siedlce.

Tatarkiewicz, W., 2003. Historia filozofii. Vol 1. PWN, Warsaw.

Urbanek, A., 2015. W poszukiwaniu teoretyczności bezpieczeństwa personalnego. Akademia Pomorska, Słupsk. 
